Acta vet. scand. $1986,27,250-256$.

From the Department of Animal Husbandry and Genetics, Norwegian College of Veterinary Medicine, Oslo, the National Veterinary Institute, Oslo, and the Department of Animal Genetics and Breeding, Agricultural University of Norway, Ås-NLH, Norway.

\title{
SERUM COMPLEMENT COMPONENT C3 LEVELS \\ IN CATTLE: GENETIC INFLUENCE AND ASSOCIATION WITH TOTAL HAEMOLYTIC ACTIVITY
}

By

M. Syed, Ø. Lie and H. Solbu

SYED, M., $\emptyset$. LIE and H. SOLBU: Serum complement component C3 levels in cattle: Genetic influence and association with total haemolytic activity. Acta vet. scand. 1986, 27, 250-256. - Serum C3 levels and total haemolytic complement (HC) activity were determined simultaneously in young bulls (130 animals, 14 sire families). 3 of the 14 families show considerable deviation in C3 levels and there was significant correlation between $\mathrm{C} 3$ and $\mathrm{HC}$.

bovine; $\mathrm{C}_{3}$ ha emolytic complement; genetics.

Complement component C3 plays an important role in generating biologically significant effects of the complement system. Activation of C3 by both classical and alternate pathways leads not only to the generation of cytolytic complex, but also produces cleavage products capable of opsonic, anaphylatoxic and chemotactic activities (Mayer 1973).

C3 is the most abundant complement component in serum, levels measuring about $130 \mathrm{mg} / 100 \mathrm{ml}$ in man (Tizard 1982). Genetically determined deficiency of $\mathrm{C} 3$ has been reported in man and guinea pigs (Alper \& Rosen 1976), and in dogs (Winkelstein et al. 1981), an autosomal recessive mode of inheritance being indicated.

Structural polymorphism of C3 has been detected by high voltage electrophoresis and isoelectric focusing in man and rhesus monkeys (Alper \& Rosen 1976), mice (Natsuume-Sakai 
et al. 1978) and in goats (Abe et al. 1984). The inheritance pattern of C3 variants is controlled by autosomal alleles with codominant expression.

Homozygous deficiency of $\mathrm{C} 3$ has been found to be associated with bacterial infections in man (Alper et al. 1972) and in dogs (Winkelstein et al. 1981). Decreased C3 levels have been reported in cattle infected with Babesia bovis (Goodger et al. 1981), and malignant catarrhal fever herpes virus (Mushi \& Rurangirwa 1981) and also in horses suffering from equine infectious anemia (Perryman et al. 1971). Zebu cattle infected with Trypanosoma congolense and Trypanosoma vivax also show a decrease in C3 levels (Rurangirwa et al. 1980).

The object of the present investigation was to determine the genetic variation of $\mathrm{C} 3$, and to study its possible relationship with total haemolytic complement $(\mathrm{HC})$.

\section{MATERIAL AND METHODS}

Sera and reagents

Serum samples were obtained from 130 young bulls the age of which ranged from 5 to 12 months. The bulls were progeny of 14 elite sires. Sera were stored at $\div 70^{\circ} \mathrm{C}$ until tested. Rabbit antibovine C3 serum was purchased from Cappel Laboratories, Downing, Pa, USA. Antiserum against rabbit erythrocytes was produced in sheep as described previously (Lie et al. 1983).

\section{C3 determination}

C3 was assayed by single radial immunodiffusion according to the method of Fahey \& McKelvey (1965) with some modifications. The agar was made up with a final concentration of $1 \%$ agarose and $1.5 \%$ rabbit anti bovine C3. A volume of $15 \mathrm{ml}$ of agar-antibody solution was poured on $10 \times 10 \mathrm{~cm}$ defatted glass slides coated with agarose. Sample wells $3 \mathrm{~mm}$ in diameter, were prepared in 6 rows of 6 into each of which $9 \mu$ l of a 1:16 dilution of the serum samples was applied. A dilution series of pooled bovine blood serum was applied as a standard. The plates were kept at room temperature in a humid chamber for $72 \mathrm{~h}$, washed in $2 \%$ sodium chloride for $24 \mathrm{~h}$, and then placed for $48 \mathrm{~h}$ in distilled water. The plates were then dried and stained with comassie blue dissolved in acidified alcohol. Diameters were determined employing a Behringwerke measuring viewer. Dia- 
meter sizes were compared to those of the dilution series of pooled bovine serum, and expressed as a percentage of this pooled normal serum value.

\section{HC assay}

Measurement of HC was carried out by a plate method according to Lachmann \& Hobart (1979) with some modification as described by Lie et al. (1986). The diameters of the lysed zones, which were proportional to the $\log _{2}$ of the concentration, were measured by a measuring viewer (Behringwerke). A twofold dilution of a bovine serum sample with high haemolytic activity was employed as a standard.

\section{Statistical methods}

The effect of sire on C3 levels was estimated by a least squares model, which also included simultaneous correction for other factors such as age, testing time and storage of samples.

A correlation analysis was applied to reveal a possible relationship between complement component C3 and HC levels.

\section{RESULTS}

Effect of sire on C3 levels

Considerable differences between sire families were observed, varying from $71.8 \pm 6.4$ to $95.4 \pm 6.4$, with an average of $85.5 \pm 1.8$. Out of a total of 14 families, a cluster of 11 showed very similar mean values, close to the average of the total material. Only 3 families showed extreme values, 2 of which were very high ( 94.9 and 95.4) and 1 of which was very low (71.8). This is also reflected by the frequency distribution as shown in Fig. 1. These three families had an average or above average number of individuals each (i.e. at least 9). The families with the extreme C3 levels differed from each other and in addition their levels differed significantly from the overall mean $(P<0.05)$.

However, no significant sire effect was found when considering the material as a whole $(P=0.28)$.

\section{Association of C3 with $\mathrm{HC}$}

In accordance with previous findings (Lie et al. 1983), a very strong sire effect (with a heritability of approx. 0.75) on total 


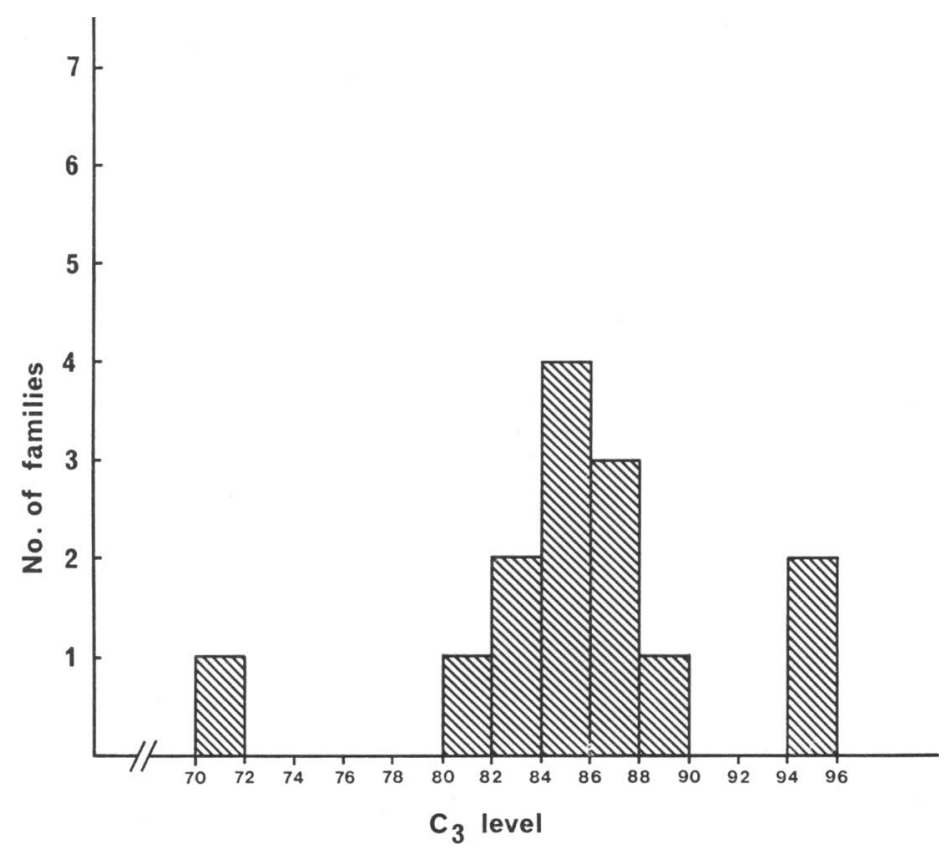

F i g u r e 1. Distribution of average serum C3 levels in 14 sire families of young bulls.

serum HC levels was demonstrated. As no general sire effect on C3 was found, a basis for estimation of genetic correlation between the 2 traits in question did not exist. However, a highly significant phenotypic correlation i.e. $r=0.30 \quad(P<0.0005)$, between $\mathrm{C} 3$ and $\mathrm{HC}$ was revealed.

This finding is also supported by the specific inhibition of $\mathrm{HC}$ by anti C3 antibody in haemolytic plate assay (Lie et al. 1986).

Effect of non-genetic mechanisms

No significant effect of age, time of testing or storage on C3 levels was found.

\section{DISCUSSION}

Of all the complement components, the only one of which an absolute deficiency appears to be life-threatening is C3, and the activation of $\mathrm{C} 3$ represents the single most important step in the complement system (see Tizard 1982). Fitness traits such as re- 
production and longevity often have intermediate or low heritability values. As C3 is likely an important trait for fitness, it is probable that genetic influence, still being exerted on C3 after long term natural selection, is either very low or non-existent.

This is in accordance with the findings in the present investigation. There was no overall significant sire effect, and C3 levels in 11 out of 14 families were clustered over a very narrow range. The values in the extreme families could of course just be a reflection of normal variation. However, the mean found in the low level family was so far below the overfall mean that some family members might have been close to a deficiency situation. This, is, however, somewhat speculative, since a deficiency limit has not been defined in cattle, and the animals studied all showed normal health.

On the other hand, the material involved was probably too limited for the purpose of genetic study. A more comprehensive material might have embraced further extreme families and consequently revealed a significant sire effect.

The existence of a positive correlation between $\mathrm{HC}$ levels and C3 levels has been reported in different studies (Rurangirwa et al. 1980, Mueller et al. 1982), which showed that decrease in $\mathrm{HC}$ level was associated with a decrease in C3 levels during infections. A significant phenotypic correlation between the 2 traits in the present investigation, as well as specific inhibition of the haemolytic cascade by anti C3 antibody (Lie et al. 1986), support these previous findings.

The present study, together with corresponding complement studies on the same material (Lie et al. 1983, Lie et al. 1986), revealed considerable individual and family variation, both with regard to total $\mathrm{HC}$ activity and $\mathrm{C} 3$ levels, $\mathrm{HC}$ proving to be subject to significant genetic control. It is likely that the limited genetic variation in $\mathrm{C} 3$ is due to the fact that nature has provided excess of this very important component. On the other hand, the mentioned relationship between $\mathrm{C} 3$ and $\mathrm{HC}$ shows clearly that corresponding haemolytic studies (Lie et al. 1983) were dealing with the terminal event of the complement system. It also shows that haemolytic plate assay (Lie et al. 1986) can be reliably used for screening purposes to monitor this very important enzyme system, including its components, since possible deficiency conditions will certainly be reflected in total HC levels. 


\section{REFERENCES}

Abe, T., A. Onishi \& T. Amano: Detection of genetic polymorphism of C3 in cattle and goat by agarose isoelectric focusing. In Summaries of XIVth Conference on Animal Blood Groups and Biochemical Polymorphisms, Göttingen 1984, p. 23.

Alper, C. A., H. R. Colten, F. S. Rosen, A. R. Rabson, G. M. Mcnab \& J. S. S. Gear: Homozygous deficiency of $\mathrm{C} 3$ in a patient with repeated infections. Lancet $1972,2,1179-1181$.

Alper, C. A. \& F. S. Rosen: Genetics of the complement system. Adv. hum. Genet. 1976, 7, 141-188.

Fahey, J. L. \& E. M. McKelvey: Quantitative determination of serum immunoglobulins in antibody-agar plates. J. Immunol. 1965, 94, $84-90$.

Goodger, B. V., I. G. Wright \& D. F. Mahoney: Changes in conglutinin, immunoconglutinin, complement $\mathrm{C} 3$ and fibronectin concentrations in cattle acutely infected with Babesia bovis. AJEBAK 1981, 59, 531-538.

Lachmann, P. J. \& M. J. Hobart: Complement technology. In: D. M. Weir (Ed.), Handbook of Experimental Immunology. Vol. 1, Immunochemistry. Blackwell Scientific Publications, Oxford etc. 1979 , pp. 5A.1-5A.23.

Lie, Ø., M. Syed \& H. Solbu: The genetic influence on serum haemolytic complement levels in cattle. Anim. Blood Grps. biochem. Genet. 1983, 14, 51-57.

Lie, Ø., M. Syed \& H. Solbu: Improved agar plate assays of bovine lysozyme and haemolytic complement activity. Acta vet. scand. $1986,27,23-32$.

Mayer, M. M.: The complement system. Scientific American 1973, 229, $54-70$.

Mueller, R., E. J. Carroll \& L. Panico: Complement C3 levels and haemolytic activity in normal and mastitic whey. Zbl. Vet. Med. B. 1982, 29, 99-106.

Mushi, E. Z. \& F. R. Rurangirwa: Immunoglobulins, haemolytic complement and serum C3 in cattle infected with malignant catarrhal fever herpesvirus. Vet. Res. Comm. 1981, 5, 57-62.

Natsuume-Sakai, S., J.-I. Hayakawa \& M. Takahashi: Genetic polymorphism of murine C3 conlrolled by a single co-dominant locus on chromosome 17. J. Immunol. 1978, 121, 491--498.

Perryman, L. E., T. C. McGuire, K. L. Banks \& J. B. Henson: Decreased C3 levels in a chronic virus infection: Equine infectious anemia. J. Immunol. 1971, 106, 1074-1078.

Rurangirwa, F. R., H. Tabel, G. Losos \& I. R. Tizard: Haemolytic complement and serum C3 levels in Zebu cattle infected with Trypanosoma congolense and Trypanosoma vivax and the effect of trypanocidal treatment. Infect. Immun. 1980, 27, 832-836.

Tizard, I. (Ed.): The complement system. In: An Introduction to Veterinary Immunology. W. B. Saunders Company, Philadelphia 1982, pp. 106-113. 
Winkelstein, J. A., L. C. Cork, D. E. Griffin, J. W. Griffin, R. J. Adams \& D. L. Price: Genetically determined deficiency of the third component of complement in the dog. Science 1981, 212, 11691170.

\section{SAMMENDRAG}

Complement komponent C3 nivåer $i$ serum hos storfe. Genetisk innflytelse og sammenheng med total hemolytisk complement.

Serum C3 nivåer ble bestemt hos ungokser (130 dyr fordelt på 14 halvs $\varnothing$ skenfamilier) samtidig med total hemolytisk complement (HC). Betydelig familievariasjon ble registrert og en signifikant korrelasjon mellom $\mathrm{C} 3 \mathrm{og} \mathrm{HC}$ ble funnet.

(Received February 24, 1986).

Reprints may be requested from: M. Syed, the Department of Animal Husbandry and Genetics, Norwegian College of Veterinary Medicine, P.O. Box 8146, Dep. N-0033, Oslo 1, Norway. 